\title{
Microbial and Enzymatic Treatment for Decolorization of Distillery Spent-Wash (DSW)
}

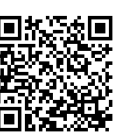

\author{
Shivam Kapoor* \\ Assistant Professor, Environmental Engineering Department, Government Engineering College, India
}

Submission: August 13, 2018; Published: August 27, 2018

*Corresponding author: Shivam Kapoor, Assistant Professor, Environmental Engineering Department, Government Engineering College, Bhuj, Gujarat, India, Email: shivamkpr88@gmail.com

\section{Mini Review}

Being rich in sugarcane yield, all the ethanol, in India, is produced by the way of fermentation of molasses and its subsequent distillation. Sugarcane juice containing sucrose is used by the sugar industry for making sugar. The residue from the sugar-making process, referred as molasses, contains high concentrations of sucrose. Molasses is used as the substrate in fermentors for producing alcohol. The liquor after fermentation contains 8-10 percent ethanol, which is further concentrated and purified in a series of distillation columns. The dark brown opaque liquid remaining after removal of alcohol is disposable and called by various names such as spent-wash, slops, stillage, still bottom, mosto, vinasse and dunder. The distillery spent wash is characterized as one of the caramelized and recalcitrant wastes containing extremely high color, COD, BOD, suspended solids and low in $\mathrm{pH}$. This spent-wash has dark brown color and needs to be decolorized before release into the natural environment. At present, there are 285 distilleries in India that producing 2.7 billion liters of alcohol and generating 40 billion liters of wastewaters annually [1]. Due to high strength of raw spent wash (high biochemical oxygen demand), application of anaerobic treatment technology with biogas recovery has been reported to be highly effective. After anaerobic treatment also effluent contains high concentrations of color and organic pollutants and as such cannot be dispose directly on land and water bodies [2]. The spent wash is highly acidic in nature and has a variety of recalcitrant coloring compounds as melanoidins, phenolics and metal sulfides that are mainly responsible for the dark color of distillery effluent [3].

\section{Nature of Melanoidins}

Distillery spent-wash contain melanoidins which are natural condensation products of sugar and amino acids produced by non-enzymatic Millard amino-carbonyl reaction taking place between the amino and carbonyl groups in organic substances. The formation of melanoidins is affected by the reactants and their concentration, type of catalysts and buffers, temperature, time $\mathrm{pH}$, water activity, presence of oxygen and metal ions [4]. Due to complex structure and xenobiotic nature of melanoidins are generally recalcitrant to biodegradation. The empirical formula of melanoidins has been suggested as $\mathrm{C}_{17-18} \mathrm{H}_{26-27} \mathrm{O}_{10} \mathrm{~N}$. Disposal of melanoidins rich wastewater reduces sun light penetration leading to decreased photosynthetic reaction and dissolved oxygen concentration in rivers, lakes and lagoons (Figure 1).

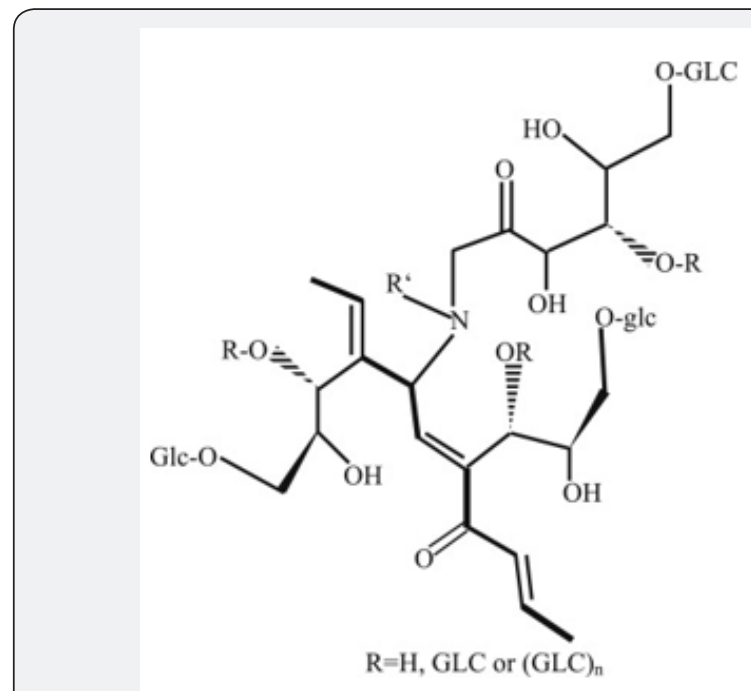

Figure 1: Basic structure of glycine-glucose melanoidin.

\section{Methods for Decolorization}

Various physical, chemical, biological and enzymatic processes for decolorization of post anaerobic treatments of spent-wash have been proposed by researchers (Figure 2). In physicochemical treatment, activated carbon as adsorbent; activated silica, bentonite, polyelectrolytes and starch as coagulant aids; ozone, single hydrogen peroxide and Fenton's reagent as oxidants were used for color removal from distillery spent-wash. All the treatment techniques gave color removal efficiency between $70-90 \%$ except single hydrogen peroxide and Fenton's reagent [5]. Although many techniques have been explored for the decolorization but they all are require high reagent dosage and produce large amount of sludge. In biological treatment color can be removed either by concentrating into the sludge or by partial/ complete breakdown of color molecules. Anaerobic treated spent wash contains high concentrations of color and organic pollutants. 


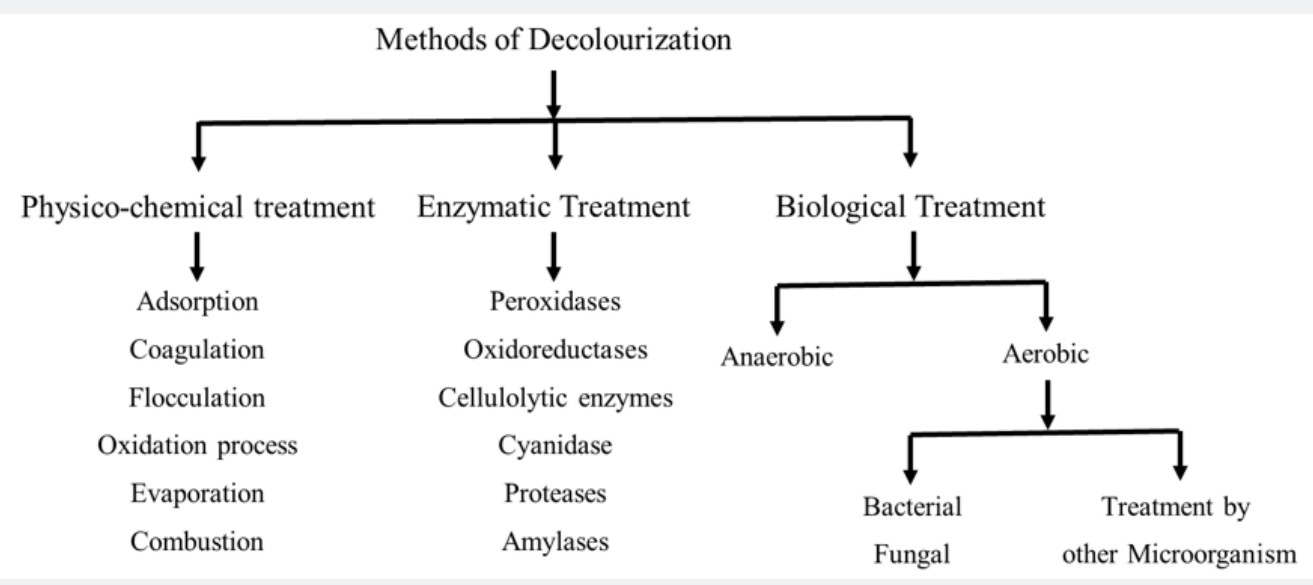

Figure 2: Various methods of decolorization.

\section{Bacterial and Fungal Treatment}

Due to the presence of high amount of organic pollutants and formation of toxic products, anaerobically treated wastewater Table 1: Literature review for bacterial and fungal decolorization. cannot be directly discharged, and it has to be treated aerobically before discharge. Some of the aerobic based methods are described below Tables $1 \& 2$.

\begin{tabular}{|c|c|c|c|c|c|}
\hline $\begin{array}{l}\text { Culture isolate or } \\
\text { Consortium }\end{array}$ & Initial Conditions & Efficiency & $\begin{array}{c}\text { Type of Color } \\
\text { Removal Method }\end{array}$ & $\begin{array}{l}\text { Optimized } \\
\text { Conditions }\end{array}$ & Author \\
\hline $\begin{array}{l}\text { Proteus mirabilis, } \\
\text { Bacillus sp., } \\
\text { Raoultella planticola } \\
\text { and Enterobacter } \\
\text { sakazakii }\end{array}$ & $\begin{array}{c}\text { MM=1000 ppm, } \\
\text { Temp. }=35^{\circ} \mathrm{C}, \\
180 \mathrm{rpm}, \\
\text { Time }=240 \mathrm{~h}\end{array}$ & $75 \%$ & $\begin{array}{c}\text { Biodegradation } \\
\text { (Confirmed by using } \\
\text { live and autoclaved } \\
\text { cells) }\end{array}$ & $\begin{array}{c}\text { Glucose, peptone, } \\
\text { Temp. }=30-35^{\circ} \mathrm{C}, \mathrm{pH} \\
=7.0, \text { Inoculum size }= \\
4: 3: 2: 1, \\
\text { Shaking speed }=100- \\
180 \mathrm{rpm}\end{array}$ & $\begin{array}{c}\text { Yadav and Chandra } \\
{[11]}\end{array}$ \\
\hline $\begin{array}{l}\text { Alcaligenes faecalis } \\
\text { SAG5 }\end{array}$ & $\begin{array}{c}\text { Temp. }=37^{\circ} \mathrm{C}, \mathrm{pH}= \\
7.0, \\
\text { MM }=0.5 \%, \\
\text { Time }=120 \mathrm{~h}\end{array}$ & $72.60 \%$ & Not specified & $\begin{array}{l}\text { Temp. }=37^{\circ} \mathrm{C}, \mathrm{pH}=7.5 \\
\text { Glucose, beef extract }\end{array}$ & Santal et al. [11] \\
\hline $\begin{array}{l}\text { Pseudomonas } \\
\text { aeruginosa PA01, } \\
\text { Stenotrophomonas } \\
\text { maltophila and } \\
\text { Proteus mirabilis }\end{array}$ & $\begin{aligned} & \text { Time }=24 \mathrm{~h}, 0.5 \% \\
& \text { glucose, static, temp } \\
&=37^{\circ} \mathrm{C}\end{aligned}$ & $67.20 \%$ & Not specified & $\begin{array}{c}\text { Glucose, Nitrogen } \\
\text { source inhibit } \\
\text { decolorization, } \mathrm{pH}= \\
\text { 7, Inoculum }=15 \% \text {, } \\
\text { Temp. }=37^{\circ} \mathrm{C} \text {, Static } \\
\text { condition }\end{array}$ & Mohana et al. [5] \\
\hline Rhizoctonia sp. D-90 & $\begin{array}{c}\text { Temp. }=30^{\circ} \mathrm{C}, \\
125 \mathrm{rpm}, \\
10 \mathrm{ml} \text { mycelial } \\
\text { suspension, } \mathrm{MM}= \\
19.3 \mathrm{ppm}, \text { time }=192 \mathrm{~h}, \\
\mathrm{pH}=6, \mathrm{NaOH}=1 \mathrm{~N}\end{array}$ & $\begin{array}{l}87.5 \% \text { and } 84.5 \% \text { in } \\
\text { molasses medium and } \\
\text { synthetic medium }\end{array}$ & $\begin{array}{l}\text { Adsorption on } \\
\text { mycelial culture }\end{array}$ & $\begin{array}{c}\mathrm{NaOH} \text { concentration }= \\
5 \mathrm{~N}\end{array}$ & $\begin{array}{c}\text { Sirianuntapiboon et } \\
\text { al. [10] }\end{array}$ \\
\hline Aspergillus niger 180 & $\begin{array}{c}\text { Temp. }=30^{\circ} \mathrm{C}, 200 \\
\text { rpm, spores conc. } \\
=10^{\wedge} 10 \text { spores } / \mathrm{L} \\
\text { time }=96 \mathrm{~h}\end{array}$ & $69 \%$ & $\begin{array}{l}83 \% \text { color removal by } \\
\text { biodegradation and } \\
17 \% \text { by adsorption. }\end{array}$ & $\begin{array}{l}\text { Sucrose }(10 \mathrm{~g} / \mathrm{L}) \\
\text { potassium phosphate } \\
(1 \mathrm{~g} / \mathrm{L}), \text { phosphate }(1 \\
\mathrm{g} / \mathrm{L}), \text { magnesium salt } \\
(100 \mathrm{mg} / \mathrm{L}), \mathrm{pH}=5.0\end{array}$ & Miranda et al. [4] \\
\hline
\end{tabular}

Table 2: Factors affecting the bacterial decolorization.

\begin{tabular}{|c|r|}
\hline Factors & Description \\
\hline $\mathrm{pH}$ & $\begin{array}{r}\text { Melanoidins solubility depends on } \mathrm{pH} \text {; it is less soluble in acidic pH than in alkaline. } \mathrm{pH} \text { higher or lower than 7.0- 7.5 } \\
\text { adversely affected the bacterial growth and degradation capability of the bacterial consortium. }\end{array}$ \\
\hline Temperature & $\begin{array}{r}\text { Optimum temperature is important for the activity of enzymes and proteins involved in degradation activity. At low } \\
\text { temperature the proteins remain inactive while at high temperature they get denatured. } \\
\text { Temperature affects the rates of microbial metabolism of melanoidins. }\end{array}$ \\
\hline
\end{tabular}




\begin{tabular}{|c|c|}
\hline Inoculum Size & $\begin{array}{c}\text { Many studies found out that } 5 \%-7 \%(\mathrm{w} / \mathrm{v}) \text { inoculum was the optimum and further increase in inoculum concentration } \\
\text { produced more fungal biomass whereas the decolonization of the medium was not improved. }\end{array}$ \\
\hline $\begin{array}{c}\text { Carbon and Nitrogen } \\
\text { Sources }\end{array}$ & $\begin{array}{c}\text { Depending upon the type of bacteria used different carbon sources has been used. Glucose is found satisfactory due to its } \\
\text { easy utilization. } \\
\text { Similar is the case with nitrogen sources. Mohana et al. [5] reported organic nitrogen at } 0.05 \% \text { (w/v) concentration showed } \\
\text { suppressive effect on decolorization and degradation of anaerobically treated distillery effluent. }\end{array}$ \\
\hline Shaking Speed & $\begin{array}{c}\text { Higher shaking speed above } 180 \mathrm{rpm} \text { suppressed the decolorization process which might be due to mechanical injury of } \\
\text { bacterial cell at high speed }\end{array}$ \\
\hline
\end{tabular}

\section{Role of Enzymes in Effluent Decolourization}

The enzymatic treatment falls between the physicochemical and biological treatment processes. It has some potential advantages over the conventional treatment. A large number of enzymes (e.g. peroxidases, oxidoreductases, cellulolytic enzymes cyanidase, proteases, amylases, etc.) from a variety of different sources play an important role waste treatment applications. Although the enzymatic system related with decolorization of melanoidins is yet to be completely understood. The white-rot fungi have a complex enzymatic system which is extracellular and non-specific, and under nutrient-limiting conditions is capable of degrading lignolytic compounds, melanoidins, and polyaromatic compounds that cannot be degraded by other microorganisms. Decolorization activity involved two types of intracellular enzymes, sugar-dependent and sugar-independent. Color removal of synthetic melanoidin by Coriolus hirsutus involved the participation of peroxidases (MnP and MIP) and the extracellular $\mathrm{H}_{2} \mathrm{O}_{2}$ produced by glucose-oxidase, without disregard of a partial participation of fungal laccase. The white-rot basidiomycete T. versicolor is an active degrader of humic acids as well as of melanoidins. Uniform, small and spongy pellets of the fungus $T$. versicolor were used as inoculum for color removal using different nutrients. Maximum color removal of $82 \%$ and $36 \%$ removal of $\mathrm{N}-\mathrm{NH}_{4}$ was obtained on using low sucrose concentration and $\mathrm{KH}_{2} \mathrm{PO}_{4}$ as the only nutrient. The enzyme laccase also helps in decolorizing melanoidins [6-11].

\section{Conclusion}

In the few last decades, interest has been developed in the field of bioremediation by using microbes. Several microorganisms such as bacteria and fungi, show a good ability to decolorize the effluent of the melanoidin based distillery industries. Thus, it can be suggested that microbial decolorization holds promise and can be exploited to develop a cost effective, eco-friendly biotechnology package for the treatment of distillery effluent. More technically advanced research efforts are required for searching, exploiting new bacterial species and improvement of practical application to propagate the use of bacteria for bioremediation of industrial effluents. Broader validation of these new technologies and integration of different methods in the current treatment schemes will most likely in the near future, render these both efficient and economically viable.

\section{References}

1. Aitken MD, Irvine RL (1989) Stability Testing of ligninase and mnperoxidase from phanerochaete chrysosporium. Biotechnology and Bioengineering 34(10): 1251-1260.

2. Benito GG, Miranda MP, Santos DR (1997) Decolorization of wastewater from an alcoholic fermentation process with Trametes Versicolor. Bioresource Technology 61(1): 33-37.

3. Cammerer B, Jaluschkov V, Kroh LW (2002) Carbohydrates structures as part of the melanoidins skeleton. International Congress Series pp. $1245-1269$.

4. Miranda PM, Benito GG, Cristobal NS, Nieto CH (1996) Color elimination from Molasses Wastewater by Aspergillus niger. Bioresource Technology 57(3): 229-235.

5. Mohana S, Desai C, Madamwar D (2007) Biodegradation and decolorization of anaerobically treated distillery spent wash by a novel bacterial consortium. Bioresource Technology 98(2): 333-339.

6. Nandy T, Shastry S, Kaul SN (2002) Wastewater management in cane molasses distillery involving bioresource recovery. Journal of Environmental Management 65(1): 25-38.

7. Raghukumar C, Mohandass C, Kamat S, Shailaja MS (2004) Simultaneous detoxification and decolorization of molasses spent wash by the immobilized White Rot Fungus Flavodon flavus isolated from a marine habitat. Enzyme and Microbial Technology 35: 197-202.

8. Santal AR, Singh NP, Saharan BS (2011) Biodegradation and detoxification of melanoidin from distillery effluent using an aerobic bacterial strain SAG5 of Alcaligenes faecalis. Journal of Hazardous Materials, 193: 319-324.

9. Santal AR, Singh NP (2013) Biodegradation of melanoidin from distillery effluent: role of microbes and their potential enzymes. Biodegradation of Hazardous and Special Products 5: 71-100.

10. Sirianuntapiboon S, Sihanonth P, Somachai P, Atthasampunna P, Hayashida S (1995) An adsorption mechanism for melanoidins decolorization by Rhizoctonia sp. Bioscience Biotechnology and Biochemistry 59(7): 1185-1189.

11. Yadav S, Chandra R (2012) Biodegradation of organic compounds of molasses melanoidin (MM) from biomethanated distillery spent wash (BMDS) during the decolorization by a potential bacterial consortium. Biodegradation 23(4): 609-620. 


\section{Your next submission with Juniper Publishers} will reach you the below assets

- Quality Editorial service

- Swift Peer Review

- Reprints availability

- E-prints Service

- Manuscript Podcast for convenient understanding

- Global attainment for your research

- Manuscript accessibility in different formats ( Pdf, E-pub, Full Text, Audio)

- Unceasing customer service

Track the below URL for one-step submission https://juniperpublishers.com/online-submission.php 